\title{
The Treatment of Hallux Valgus
}

Nikolaus Wülker, Falk Mittag

\section{SUMMARY}

Background: Hallux valgus is the commonest forefoot deformity, with an estimated prevalence of $23 \%$ to $35 \%$. It causes symptoms on the medial edge of the foot, the sole, and the small toes. Non-operative treatment may alleviate symptoms but does not correct the deformity of the big toe. Surgery is indicated if the pain persists. The correct operation must be selected from a wide variety of available techniques.

Methods: In this article, we selectively review the pertinent literature, including the recommendations of medical societies in Germany and abroad, in the light of our own clinical experience.

$\underline{\text { Results: }}$ There have been many clinical trials of various treatments for hallux valgus, but very few of these were randomized, and the case numbers were generally small. Mild deformities are best treated by distal first metatarsal osteotomies, e.g. the Chevron osteotomy. Severe deformities require a soft-tissue procedure at the first metatarsophalangeal joint and a proximal first metatarsal osteotomy. In case of osteoarthritis, and in elderly patients, a resection arthroplasty is preferred; arthrodesis is performed in physically active patients. After correction of hallux valgus, patients can usually bear their full weight on the treated foot while wearing a flat surgical shoe. Proper surgical treatment results in a good or very good outcome in $85 \%$ of patients and a satisfactory result in a further $10 \%$.

Conclusion: The clinical outcome of present treatments seems to be good in most cases, but large-scale randomized trials are still needed to verify the efficacy of the wide variety of operations and fixation techniques that are currently being offered.

- Cite this as:

Wülker N, Mittag F: The treatment of hallux valgus. Dtsch Arztebl Int 2012; 109(49): 857-68.

DOI: 10.3238/arztebl.2012.0857
$\mathbf{N}$ o deformity of the forefoot occurs more frequently than hallux valgus. A recent review estimates the global prevalence of hallux valgus at up to $23 \%$ in 18 - to 65 -year-olds and $35 \%$ in those over 65 , although of course it is difficult to draw a line between normal and pathological positioning of the great toe (1). The reasons for hallux valgus in an individual case are hard to define: The deformity can often be attributed to ill-fitting shoes, and sometimes there is a familial disposition. Women are much more commonly affected than men, because they frequently wear narrow, high-heeled shoes and often have more flexible soft tissues (2). Although hallux valgus is particularly frequent from the middle years of life upwards, many patients of both sexes are affected at a young age, usually in one foot but sometimes in both (1-3, e1-e3).

The pathogenesis of hallux valgus is complex. It is generally accepted that an imbalance of the extrinsic and intrinsic foot muscles and the ligamentous structures is involved. Even in the normal foot, the extensor and flexor tendons are slightly off-center to lateral. This is compensated by other foot muscles and ligaments, however, so that overall the forces are balanced. This equilibrium is sensitive to internal and external influences (e.g., the wearing of narrow, high-heeled, and pointed shoes). The energy required to maintain the developing deformity becomes ever smaller. The eventual result is valgus deformity of the great toe with spreading of the forefoot (3-6, e3).

Hallux valgus causes symptoms in three particular ways. First and foremost is pain in the bunion, the pressure-sensitive prominence on the medial side of the head of the first metatarsal. It hurts to wear a shoe. Furthermore, the valgus deviation of the great toe often results in a lack of space for the other toes. They become displaced, usually upwards, leading to pressure against the shoe. This is termed hammer toe or claw toe. Finally, normal function of the forefoot relies heavily on the great toe pressing down on the ground

\section{Symptoms}

Hallux valgus causes pain particularly in the bunion on the inner side of the foot, on loading under the foot and in the smaller toes 


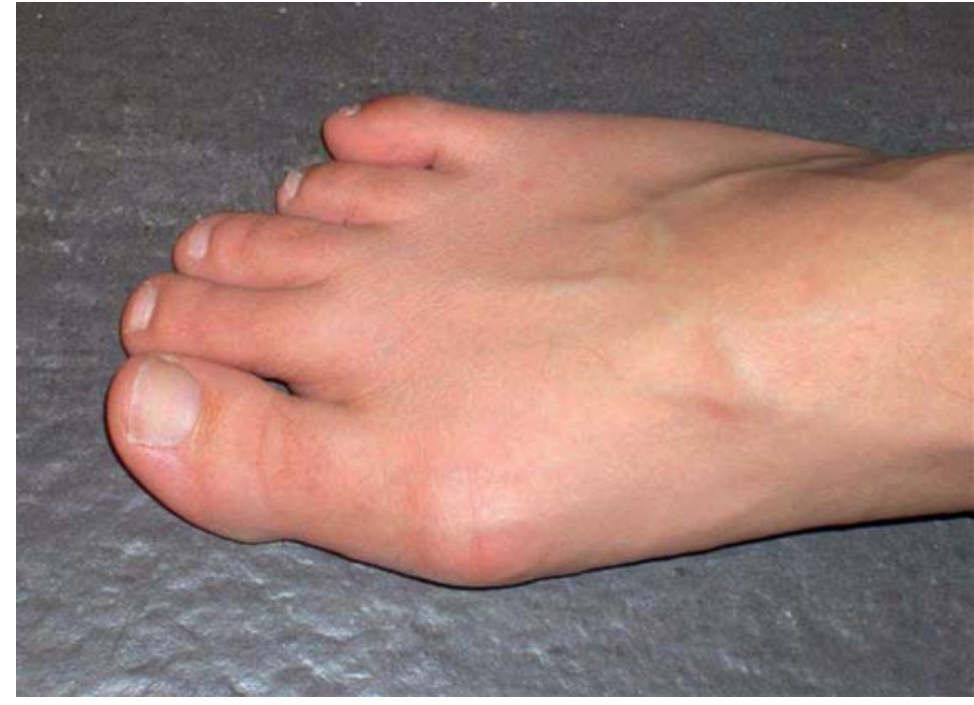

Figure 1: Hallux valgus with a hallux valgus angle of $20^{\circ}$ and pain from pressure on the bunion medially position of the great toe is not the only deformity. In the majority of cases the metatarsus is splayed, increasing the prominence of the metatarsophalangeal joint. Moreover, the great toe is often somewhat pronated, so that the nail faces medially. The examiner should also establish whether the deformity is flexible, i.e., whether it can be corrected by manipulation, and whether motion of the metatarsophalangeal joint is limited by pain, which would point to osteoarthritis. Furthermore, the stability of the first tarsometatarsal joint should be determined. The tarsus and hindfoot must also be investigated to exclude accompanying deformities. Investigation of peripheral vascular perfusion and motor and sensory functions is obligatory.

A dorsoplantar radiograph with the foot under load is required. An additional lateral or oblique view in this position contributes little extra information because the bones are superimposed, but may help to depict deformities of the smaller toes and instability of neighboring joints. Only under conditions of loading can the angle between the first and second metatarsals (intermetatarsal angle) be determined accurately. The radiograph will show the congruence of the metatarsophalangeal joint, i.e., whether a subluxation exists, and should also be inspected for any signs of osteoarthritis (joint space narrowing, subchondral sclerosis). pening to a sufficient degree, metatarsal heads II-V are overloaded. The resulting pain is referred to as transfer metatarsalgia.

\section{Learning goals}

The learning goals for readers of this article are:

- The ability to distinguish accurately between the different variants of hallux valgus deformity

- Attainment of familiarity with the possibilities and limitations of conservative, symptomatic treatment of hallux valgus

- The ability to decide when surgery is indicated

- Acquaintance with the various surgical procedures and the indications for each particular method.

\section{Diagnosis}

The lateral deviation of the great toe is obvious when the patient stands barefoot (Figure 1). In addition, one can measure the angle between the longitudinal axes of the first metatarsal and the proximal phalanx of the great toe, with the vertex at the head of the first metatarsal (hallux valgus angle). An angle greater than $15^{\circ}$ no longer corresponds to the norm, although there is considerable interindividual variation (3). The valgus

\section{Conservative treatment}

Only while the skeleton is still growing can the position of the great toe be improved with lasting effect. A night splint can be prescribed to move the great toe to medial. After the end of growth, adequate correction is no longer possible and conservative treatment is restricted to alleviation of symptoms.

By the time patients consult a physician, most of them have already resorted to softer and wider shoes to alleviate pain from pressure on their bunion. Ring pads and other dressings tend to increase the prominence of the bunion and are usually unsuccessful. Antiphlogistic salves can be administered locally, nonsteroidal antiinflammatory drugs systemically.

Pain in the smaller toes can be alleviated with pads and toe straighteners. Wide, soft shoes are helpful if they give the toes enough space. Once hammer toes or claw toes have developed, however, surgery is necessary.

In our experience, insoles are effective for alleviation of metatarsalgia (7). They must feature a pad that pushes the metatarsals upward proximal to the

\section{Radiograph}

A radiograph with the patient in standing position shows the angle between metatarsal I and metatarsal II, as well as the congruence of the first metatarsophalangeal joint and any signs of osteoarthritis.

\section{Conservative treatment}

Pain on standing and walking can be alleviated by inlays under the forefoot. Permanent improvement of the position of the great toe is not possible. 


\section{A selection of well-known surgical procedures for treatment of hallux valgus}

\begin{tabular}{|c|c|c|c|c|c|c|}
\hline No. & Name & Principle & Site & References & Advantages/disadvantages & Comments \\
\hline 1 & Akin & $\begin{array}{l}\text { Corrective osteo- } \\
\text { tomy }\end{array}$ & $\begin{array}{l}\text { Proximal } \\
\text { phalanx }\end{array}$ & $\begin{array}{l}\text { Akin (1925) (8), } \\
\text { Arnold (2008) (e4), } \\
\text { Chacon et al. (2012) (9) }\end{array}$ & $\begin{array}{l}\text { In combination with other techniques, } \\
\text { stability technically difficult }\end{array}$ & $\begin{array}{l}\text { Used in hallux valgus in- } \\
\text { terphalangeus }\end{array}$ \\
\hline 2 & $\begin{array}{l}\text { Metatarsophal- } \\
\text { angeal joint } \\
\text { arthrodesis }\end{array}$ & Fusion & $\begin{array}{l}\text { Metatarsopha- } \\
\text { langeal joint }\end{array}$ & Kumar et al. (2010) (10) & $\begin{array}{l}\text { Permanent correction, } \\
\text { loss of mobility, } \\
\text { subsequent osteoarthritis }\end{array}$ & $\begin{array}{l}\text { Used in severe deformi- } \\
\text { ties and/or hallux rigidus }\end{array}$ \\
\hline 3 & $\begin{array}{l}\text { Basal osteoto- } \\
\text { my }\end{array}$ & $\begin{array}{l}\text { Corrective oste- } \\
\text { otomy }\end{array}$ & $\begin{array}{l}\text { Metatarsal I, } \\
\text { proximal }\end{array}$ & $\begin{array}{l}\text { Mann (1992) (11), } \\
\text { Wülker (2005) (12) }\end{array}$ & $\begin{array}{l}\text { In combination with soft tissue interven- } \\
\text { tion, stability technically difficult, } \\
\text { implant necessary, not possible if tarso- } \\
\text { metatarsal joint is unstable }\end{array}$ & $\begin{array}{l}\text { Suitable for correction of } \\
\text { severe deformities }\end{array}$ \\
\hline 4 & Chevron & $\begin{array}{l}\text { Corrective oste- } \\
\text { otomy }\end{array}$ & $\begin{array}{l}\text { Metatarsal I, } \\
\text { distal }\end{array}$ & $\begin{array}{l}\text { Austin (1981) (13), } \\
\text { Wülker (2005) (12) }\end{array}$ & $\begin{array}{l}\text { Reliable technique, little soft tissue trau- } \\
\text { ma, implant necessary, not possible } \\
\text { with severe deformity, reduced perfu- } \\
\text { sion of head of metatarsal I }\end{array}$ & Used in mild deformities \\
\hline 5 & Hohmann & $\begin{array}{l}\text { Corrective oste- } \\
\text { otomy }\end{array}$ & $\begin{array}{l}\text { Metatarsal I, } \\
\text { distal }\end{array}$ & Hohmann (1923) (14) & $\begin{array}{l}\text { Little stability with wires or sutures, re- } \\
\text { duced perfusion of head of metatarsal I }\end{array}$ & Now hardly ever used \\
\hline 6 & Hueter & $\begin{array}{l}\text { Resection arthro- } \\
\text { plasty }\end{array}$ & $\begin{array}{l}\text { Metatarsal I, } \\
\text { head }\end{array}$ & $\begin{array}{l}\text { Hueter (1871) (15), } \\
\text { Mayo (1908) (e6) }\end{array}$ & $\begin{array}{l}\text { Simple technique, lack of support for } \\
\text { head of metatarsal I, transfer metatar- } \\
\text { salgia frequent }\end{array}$ & No longer used \\
\hline 7 & Keller-Brandes & $\begin{array}{l}\text { Resection arthro- } \\
\text { plasty }\end{array}$ & $\begin{array}{l}\text { Proximal pha- } \\
\text { lanx, proximally }\end{array}$ & $\begin{array}{l}\text { Keller (1904) (16), } \\
\text { Brandes (1929) (17) }\end{array}$ & $\begin{array}{l}\text { Simple technique, loss of hallux func- } \\
\text { tion, transfer metatarsalgia frequent }\end{array}$ & $\begin{array}{l}\text { Used in elderly and } \\
\text { inactive patients }\end{array}$ \\
\hline 8 & Kramer & $\begin{array}{l}\text { Corrective oste- } \\
\text { otomy }\end{array}$ & $\begin{array}{l}\text { Metatarsal I, } \\
\text { distal }\end{array}$ & Kramer (1990) (18) & $\begin{array}{l}\text { Little stability with wires, reduced perfu- } \\
\text { sion of head of metatarsal I }\end{array}$ & Now hardly ever used \\
\hline 9 & Lapidus & Fusion & $\begin{array}{l}\text { Tarsometatar- } \\
\text { sal joint }\end{array}$ & $\begin{array}{l}\text { Lapidus (1934) (19), } \\
\text { Taylor et al. (2008) (20), } \\
\text { Hyer et al. (2011) (e7) }\end{array}$ & $\begin{array}{l}\text { In combination with soft tissue interven- } \\
\text { tion, implant necessary, loss of mobility, } \\
\text { technically difficult, danger of pseudar- } \\
\text { throses }\end{array}$ & $\begin{array}{l}\text { Used in cases of TMT-I } \\
\text { joint instability or osteo- } \\
\text { arthritis }\end{array}$ \\
\hline 10 & McBride & $\begin{array}{l}\text { Soft tissue balanc- } \\
\text { ing with reposition- } \\
\text { ing of the adductor } \\
\text { tendon }\end{array}$ & $\begin{array}{l}\text { Metatarsopha- } \\
\text { langeal joint }\end{array}$ & McBride (1928) (21) & $\begin{array}{l}\text { Frequent recurrence owing to inade- } \\
\text { quate correction of metatarsal I }\end{array}$ & $\begin{array}{l}\text { Now hardly ever used, } \\
\text { replaced by soft tissue } \\
\text { procedure }\end{array}$ \\
\hline 11 & Scarf & $\begin{array}{l}\text { Corrective oste- } \\
\text { otomy }\end{array}$ & $\begin{array}{l}\text { Metatarsal I, } \\
\text { diaphyseal }\end{array}$ & $\begin{array}{l}\text { Patton et al. (1994) } \\
\text { (e8), Weil (2000) (22), } \\
\text { Adam et al. (2011) (e9) }\end{array}$ & $\begin{array}{l}\text { Accurate correction angle, implant ne- } \\
\text { cessary, extensive soft tissue dissection }\end{array}$ & $\begin{array}{l}\text { Suitable for correction of } \\
\text { mild to moderate defor- } \\
\text { mities }\end{array}$ \\
\hline 12 & $\begin{array}{l}\text { Soft tissue } \\
\text { procedure }\end{array}$ & $\begin{array}{l}\text { Soft tissue balanc- } \\
\text { ing }\end{array}$ & $\begin{array}{l}\text { Metatarsopha- } \\
\text { langeal joint }\end{array}$ & Mann (1992) (4) & $\begin{array}{l}\text { Complete soft tissue correction, two } \\
\text { skin incisions necessary }\end{array}$ & $\begin{array}{l}\text { Usually in combination } \\
\text { with proximal osteotomy }\end{array}$ \\
\hline
\end{tabular}

\section{Surgical procedures}

The different surgical procedures are based on various underlying principles, e.g., correction osteotomy, resection arthroplasty, or arthrodesis.

\section{Disadvantage of some operative techniques}

A disadvantage of some operative techniques is reduced perfusion of the head of metatarsal I. 


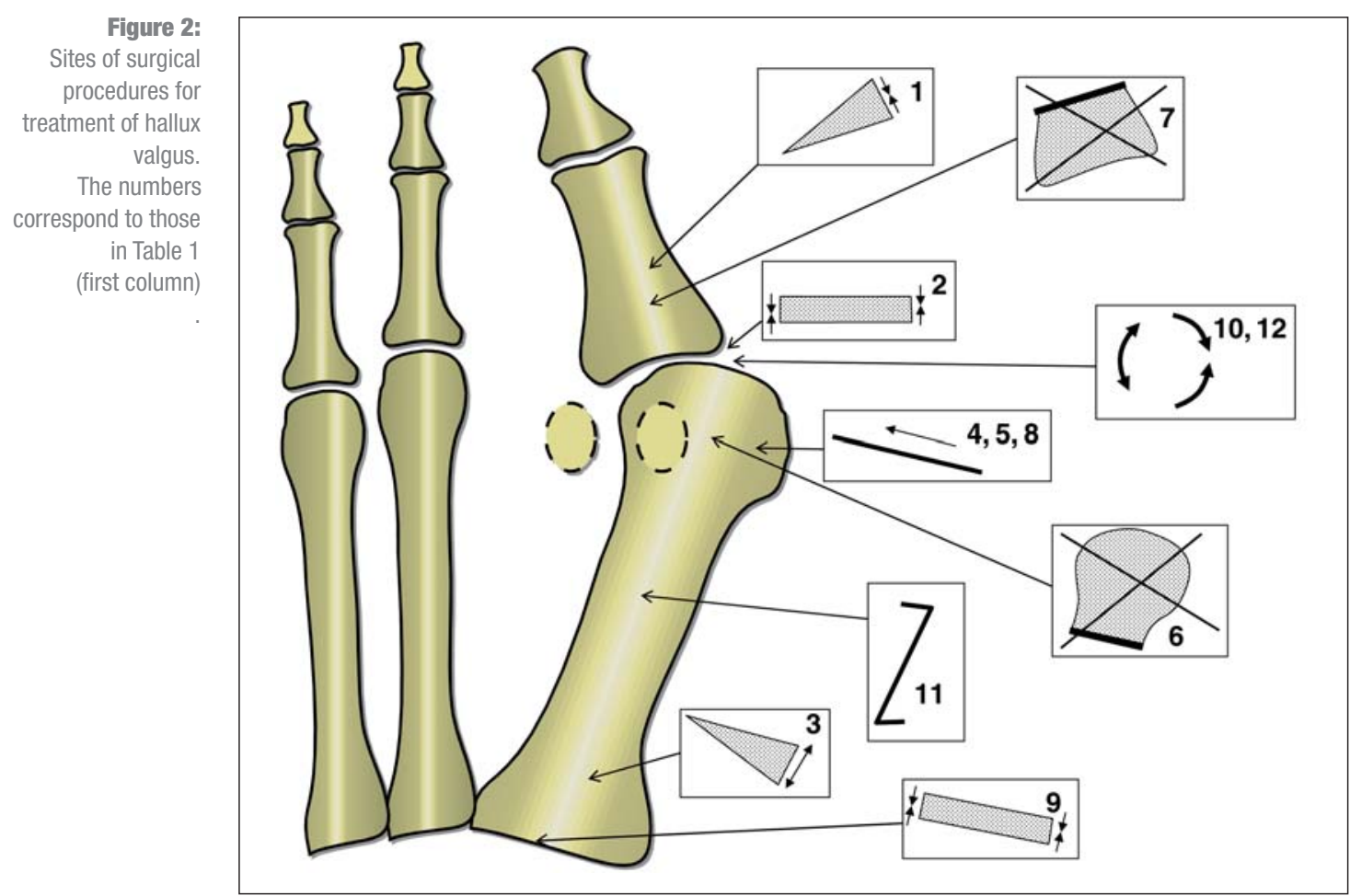

pressure-sensitive heads. It often suffices to advise the patient to wear shoes with soft soles and without excessively high heels (no more than $4 \mathrm{~cm}$ ). The malposition of the great toe, of course, cannot be corrected with insoles alone.

\section{Study findings}

Over 150 different operations have been described for the treatment of hallux valgus. A selection of betterknown procedures is presented in Table 1 and Figure 2.

There are only a small number of prospective randomized trials comparing different surgical procedures or investigating conservative treatment (Table 2). The whole published literature contains only four publications $(23,29-31)$ in which operative techniques were compared, none of which reached any clear conclusions. This shows the limits of current scientific knowledge, particularly when it comes to detailed questions of surgery. Whether, for example, the adductor tendon must be divided or the intermetatarsal angle corrected has to be decided according to the patient's specific deformity. These techniques can hardly be randomized without taking account of the exact deformity. The wide variety of deformities would necessitate very large numbers of cases, involving the cooperation of many different centers. For this reason, prospective randomized trials concern themselves with details of surgical technique or compare very similar operations. The actual choice of procedure over the whole spectrum of hallux valgus deformities thus depends essentially on the surgeon's expertise and experience.

A Cochrane review by a group of podiatrists in London, originally published in 2004 and updated in 2009 , analyzed a total of 21 randomized or "quasirandomized" clinical trials that were essentially equivalent to the studies listed in Table 2 with regard to operative technique. The conclusion: "The methodological quality of the [...] trials was generally poor and trial sizes were small." No difference was found between conservative treatment and no treatment. No recommendations were given with regard to operative techniques. Trials of operative techniques have yielded

\section{Metatarsalgia}

In our experience, metatarsalgia can be effectively alleviated with insoles. These must have a pad that exerts upward pressure on the metatarsals proximal to the pressure-sensitive metatarsal heads.

\section{Study findings}

The literature contains only few prospective randomized trials comparing different surgical procedures or investigating conservative treatment. Four studies that did compare procedures all came to no clear conclusion. 


\section{Randomized clinical trials of hallux valgus surgery}

\begin{tabular}{|c|c|c|c|c|}
\hline Study [reference] & Comparison & $\begin{array}{l}\text { Number of } \\
\text { patients }\end{array}$ & Results & Comments \\
\hline $\begin{array}{l}\text { Klosok et al. } \\
\text { (1993) [23] }\end{array}$ & $\begin{array}{l}\text { Chevron osteotomy versus } \\
\text { Wilson osteotomy }\end{array}$ & 87 & $\begin{array}{l}\text { Quicker return to work with Chevron os- } \\
\text { teotomy, better functional outcome with } \\
\text { Wilson osteotomy }\end{array}$ & $\begin{array}{l}\text { Three years' follow-up, Wilson osteotomy } \\
\text { now hardly ever used }\end{array}$ \\
\hline $\begin{array}{l}\text { Resch et al. } \\
\text { (1994) [24] }\end{array}$ & $\begin{array}{l}\text { Chevron osteotomy with ver- } \\
\text { sus without adductor tenotomy }\end{array}$ & 84 & $\begin{array}{l}\text { Hallux correction } 9.8^{\circ} / 7.5^{\circ} \text { with/without } \\
\text { tenotomy, no other differences }\end{array}$ & $\begin{array}{l}\text { Limited relevance, because capsule not } \\
\text { divided }\end{array}$ \\
\hline $\begin{array}{l}\text { Connor et al. } \\
\text { (1995) [25] }\end{array}$ & $\begin{array}{l}\text { Rehabilitation with versus } \\
\text { without continuous motion } \\
\text { after Chevron osteotomy }\end{array}$ & 39 & Mobility better with continuous motion & $\begin{array}{l}\text { Only } 90 \text { days' follow-up, limited relevance } \\
\text { for treatment }\end{array}$ \\
\hline $\begin{array}{l}\text { Easley et al. } \\
\text { (1996) [26] }\end{array}$ & $\begin{array}{l}\text { Curved versus proximal } \\
\text { Chevron osteotomy }\end{array}$ & 97 & $\begin{array}{l}\text { No significant differences regarding cor- } \\
\text { rection, but swifter and more reliable } \\
\text { healing with proximal Chevron osteotomy }\end{array}$ & $\begin{array}{l}\text { Only } 2 \text { years' follow-up, various fixation } \\
\text { techniques, limited relevance for treat- } \\
\text { ment }\end{array}$ \\
\hline $\begin{array}{l}\text { Calder et al. } \\
\text { (1999) [27] }\end{array}$ & $\begin{array}{l}\text { Suture versus screw fixation in } \\
\text { Mitchell osteotomy }\end{array}$ & 30 & Better results with screws & $\begin{array}{l}\text { Superior stability with screws was to be } \\
\text { expected, Mitchell osteotomy now seldom } \\
\text { used }\end{array}$ \\
\hline $\begin{array}{l}\text { Torkki et al. } \\
\text { (2003) [28] }\end{array}$ & $\begin{array}{l}\text { Surgery versus } 1 \text {-year conser- } \\
\text { vative treatment with or with- } \\
\text { out orthesis }\end{array}$ & 209 & $\begin{array}{l}\text { Surgery superior to conservative treat- } \\
\text { ment after } 1 \text { year, no difference after } 2 \\
\text { years }\end{array}$ & Unclear interpretation of data \\
\hline $\begin{array}{l}\text { Faber et al. } \\
(2004)[29]\end{array}$ & $\begin{array}{l}\text { Hohmann osteotomy versus } \\
\text { Lapidus operation }\end{array}$ & 101 & $\begin{array}{l}\text { No significant difference, also not with re- } \\
\text { gard to hypermobility of first tarsometatar- } \\
\text { sal joint }\end{array}$ & $\begin{array}{l}\text { No severe deformities included, } \\
\text { only } 2 \text { years' follow-up }\end{array}$ \\
\hline $\begin{array}{l}\text { Saro et al. } \\
(2007)[30]\end{array}$ & $\begin{array}{l}\text { Lindgren versus Chevron } \\
\text { osteotomy }\end{array}$ & 100 & $\begin{array}{l}\text { No significant differences, both proce- } \\
\text { dures suitable only for mild deformities }\end{array}$ & $\begin{array}{l}\text { Long follow-up ( } 6 \text { years); comparison of } \\
\text { two very similar techniques; Lindgren } \\
\text { techniques now seldom used }\end{array}$ \\
\hline $\begin{array}{l}\text { Deenik et al. } \\
\text { (2008) [31] }\end{array}$ & $\begin{array}{l}\text { Scarf osteotomy versus } \\
\text { Chevron osteotomy }\end{array}$ & 136 & $\begin{array}{l}\text { No significant differences, good results in } \\
\text { both groups }\end{array}$ & $\begin{array}{l}\text { Comparison of two very similar tech- } \\
\text { niques; the authors recommend Chevron } \\
\text { osteotomy because it is technically } \\
\text { simpler }\end{array}$ \\
\hline $\begin{array}{l}\text { Tonbul et al. } \\
\text { (2009) [32] }\end{array}$ & $\begin{array}{l}\text { Screw versus K-wires for sta- } \\
\text { bilization; curved, distal meta- } \\
\text { tarsal osteotomy }\end{array}$ & 16 & $\begin{array}{l}\text { No significant differences, good results in } \\
\text { both groups }\end{array}$ & $\begin{array}{l}\text { Groups too small, limited relevance for } \\
\text { treatment }\end{array}$ \\
\hline $\begin{array}{l}\text { du Plessis et al. } \\
\text { (2011) [33] }\end{array}$ & $\begin{array}{l}\text { Exercises versus night splint } \\
\text { in conservative hallux valgus } \\
\text { treatment }\end{array}$ & 30 & No difference between the groups & Groups too small \\
\hline $\begin{array}{l}\text { Pentikäinen et al. } \\
\text { (2012) [34] }\end{array}$ & $\begin{array}{l}\text { Chevron osteotomy with fixa- } \\
\text { tion (resorbable peg) versus } \\
\text { no fixation, with plaster versus } \\
\text { elastic bandage postopera- } \\
\text { tively }\end{array}$ & 100 & $\begin{array}{l}\text { Osteotomy displacement } 3.9 \mathrm{~mm} \text { with } \\
\text { fixation versus } 3.1 \mathrm{~mm} \text { without fixation } \\
\text { (statistically significant), no difference for } \\
\text { postoperative treatment }\end{array}$ & $\begin{array}{l}\text { Accuracy of measurement technique not } \\
\text { described, difference clinically irrelevant }\end{array}$ \\
\hline
\end{tabular}

\section{Operative techniques}

Whether, for example, the adductor tendon should be divided or the intermetatarsal angle corrected has to be decided according to the individual deformity.

\section{Trials}

All randomized controlled trials had case numbers that were too small and follow-up periods that were too short. 
FIGURE 3

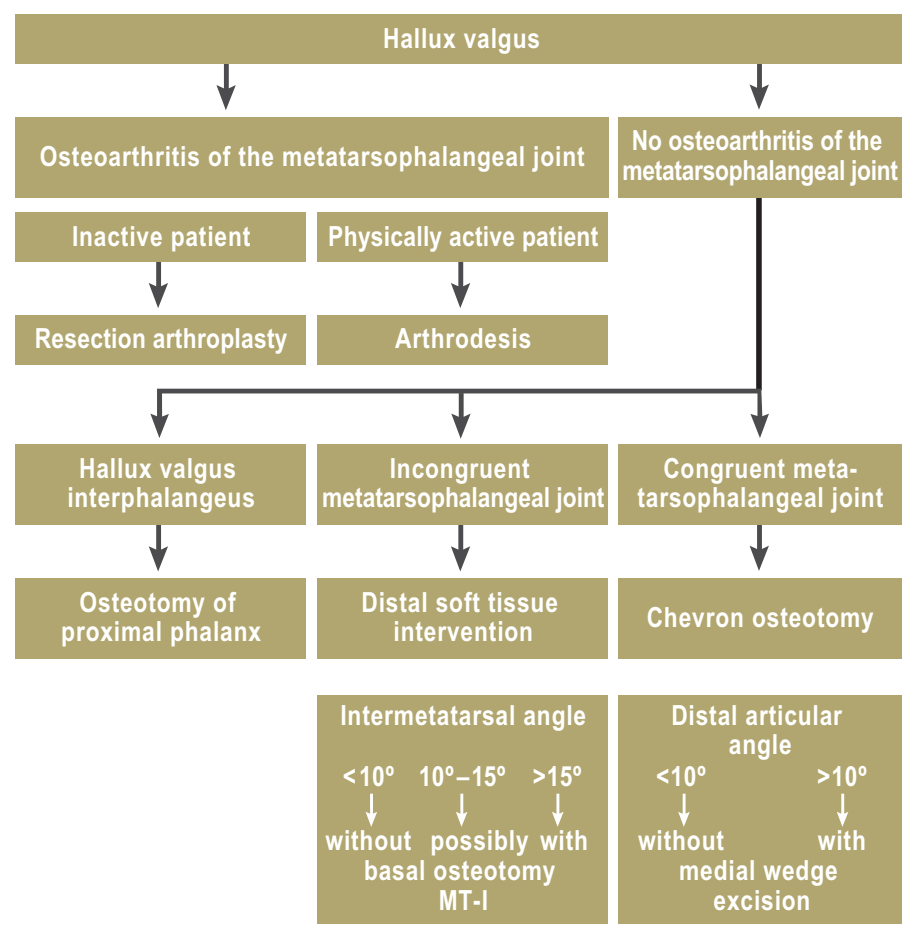

The algorithm used at our institution to classify hallux valgus and select the most appropriate surgical procedure. This algorithm broadly corresponds to other published recommendations (36). Distal and proximal repositioning of metatarsal I and arthrodesis can be accomplished by means of various osteotomies and fixation techniques. MT-I, metatarsal I

inconsistent results; no one technique was superior to all others. Notably, in some studies $25 \%$ to $33 \%$ of patients were unsatisfied with the outcome of the operation although the relevant angles were improved. The authors of the Cochrane review criticized the maximal 3 years' postoperative follow-up, writing that 20 to 30 years would be desirable (35).

The German Orthopaedic Foot and Ankle Society (DAF), a section of the German Society for Orthopaedics and Orthopaedic Surgery (DGOOC), has issued an S1 guideline on hallux valgus (36). On the basis of studies yielding evidence of levels III and IV, an algorithm was set up that distinguishes between mild, moderate, and severe deformities and lists distal, diaphyseal, and proximal osteotomies and arthrodesis of the first tarsometatarsal joint as surgical options. Each procedure can be used for all deformities, with two exceptions: proximal osteotomy and arthrodesis should not be employed for mild deformities, and distal osteotomy is not appropriate for severe hallux valgus. The guideline includes the following recommendations without giving any references: division of the soft tissues lateral to the metatarsophalangeal joint in severe deformities; corrective retrocapital osteotomy in the presence of a tilted joint surface; resection arthroplasty in the case of poor mobility; shortening of metatarsal I in osteoarthritis of the metatarsophalangeal joint. Therefore, although the guideline is formulated in quite general terms, its recommendations essentially correspond to those given here. An example of the other reviews on the treatment of hallux valgus is that published by Wanivenhaus et al. (37).

In the face of the high number of different operations described and the mostly low level of evidence of the investigations published, it is extremely difficult to give treatment recommendations based on high-level evidence. The surgical procedures described in this review reflect the practice in our own institution. Other procedures that are not discussed here may be equally suitable, but any surgery must be specifically designed to eliminate the deformity concerned.

\section{Indications for surgery}

Cosmetic surgery is out of place in hallux valgus. The danger is far too great that a previously symptom-free patient will suffer pain for weeks or even months after the intervention. For surgical treatment to be indicated, the patient must have pain that is not alleviated by a simple change of shoes or by other, conservative treatments. Moreover, the pain must be regular in occurrence and must noticeably impair the function of the affected foot.

The pain does not necessarily have to involve the great toe itself. Patients often initially complain of pain arising from the other digits, which may already have been forced upwards as hammer or claw toes. In such a case it is not enough to correct the deformity of the smaller toes; the hallux valgus must be rectified.

The principal contraindication to surgery is arterial occlusive disease (e10). Because it is the part of the body most distant from the heart, the foot is the first place where decreased perfusion will make itself

\section{Algorithm}

Metatarsophalangeal joint with or without osteoarthritis, congruent or incongruent metatarsophalangeal joint, patient with high or low degree of physical activity.

\section{Level of evidence}

In the face of the high number of different operations described and the mostly low level of evidence of the investigations published, it is impossible to give treatment recommendations based on high-level evidence. 
noticed. If the pedal pulse is not distinct, the vascular status must be determined. Only if sufficient perfusion is assured can surgery take place.

Diabetes, even with early polyneuropathy, does not represent a contraindication. Hallux valgus can also be treated surgically in the presence of chronic polyarthritis or other rheumatic diseases, although care must be taken to select an appropriate procedure.

\section{Operative technique}

The soft tissue covering of the foot is extremely thin, and this hampers wound healing. Furthermore, perfusion is poorest in the foot because of its distance from the heart. Finally, of all parts of the body the foot is subjected to the greatest mechanical stresses. For these reasons wound healing problems, depending on the extent of the operation and the patient's medical history, occur more frequently in the foot than in most other regions. The aim is uncomplicated wound healing in at least $99 \%$ of patients, in our experience an attainable goal. Particular care must therefore be taken when operating on the great toe. The duration of ischemia must be as short as possible. This is best achieved by wrapping a tourniquet around the foot after sterile draping. The incision should grant direct access to the operation site without undue dissection of soft tissues. There should be no hemostasis by means of electrocautery. Excessive retraction should be avoided. Care must be taken to ensure proper compression by the bandage applied postoperatively. Only dry bandages may be used in order to avoid maceration of the wound margins. The suture for wound closure should be left in place until 14 days after surgery. Although functional rehabilitation under full loading is generally possible, the foot must be elevated to avoid excessive swelling.

\section{Surgical procedures}

To be able to cope with all variants of hallux valgus, the surgeon needs a command of around four procedures. The basic distinction is between operations that restore the normal anatomy of the forefoot, and thus come into question particularly in younger patients, and interventions where the joint is sacrificed (resected or fused), which are considered especially in older patients and in the case of osteoarthritis of the metatarsophalangeal joint $(12,38,39)$.

Figure 3 provides an overview of the classification of hallux valgus and the commonest surgical procedures. These will be described in detail in the following.
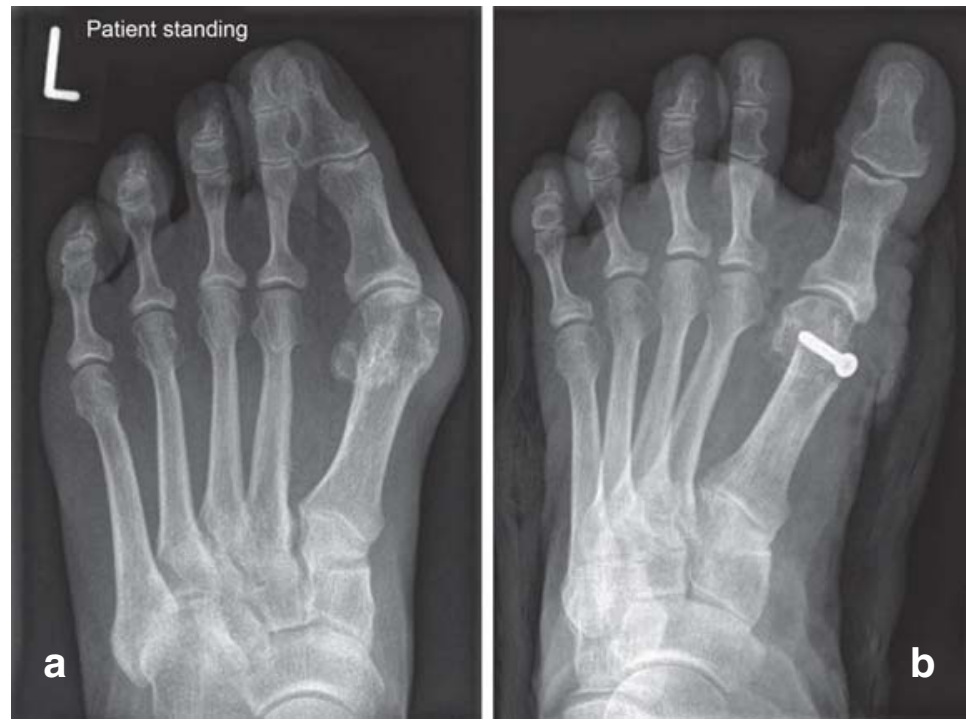

Figure 4: Radiographs of a foot with mild hallux valgus

a) Mild malposition with an intermetatarsal angle of $13^{\circ}$, a congruent metatarsophalangeal joint, and a flexible deformity

b) After correction by Chevron osteotomy: the head of metatarsal I was shifted $5 \mathrm{~mm}$ to lateral and the capsule on the medial side of the first metatarsophalangeal joint was tightened

\section{Mild deformities}

Mild deformities are found predominantly in young women (Figure 4a). The patients complain principally of pressure pain in the bunion, which is moderately prominent. The deformity is flexible, i.e., the hallux can be restored to the normal position manually, without any significant resistance. Moreover, the metatarsus is only slightly splayed, so that the intermetatarsal angle is less than $15^{\circ}$ on a weight bearing radiograph. The mobility of the first metatarsophalangeal joint is not restricted, and no osteoarthritis is seen on the radiograph. Mild deformities can be effectively treated by distal metatarsal I osteotomies, e.g., chevron osteotomy (Figure 4b). This intervention, initially known as Austin osteotomy, was first described in 1962 (13). A $\mathrm{V}$-shaped cut is made in the head of metatarsal I and the bone is displaced laterally by one third to a half of its width, thus correcting the intermetatarsal angle. In addition, the exostosis on the medial aspect of the head of metatarsal I is shaved off and the capsule tightened so that by the end of the operation the great toe is in the proper position. Fixation with a small implant is

\section{Surgical procedure according to deformity}

The success of an operation depends crucially on the selection of the best procedure for the individual deformity.

\section{Contraindication}

The principal contraindication to surgery is arterial occlusive disease. 

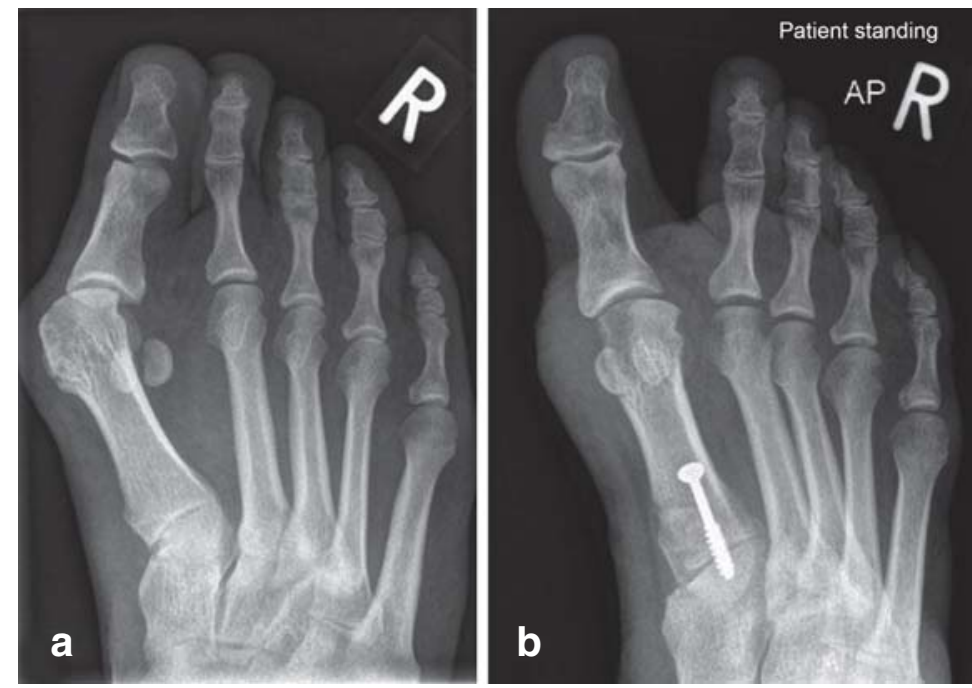

Figure 5: Radiographs of a foot with severe hallux valgus

a) Severe deformity with an intermetatarsal angle of $19^{\circ}$, an incongruent metatarsophalangeal joint, and a rigid deformity

b) After correction by a distal soft tissue intervention with release of the soft tissues on the lateral side and tightening of the soft tissues on the medial side of the metatarsophalangeal joint, with additional correction of the position of metatarsal I by an osteotomy at its base necessary to prevent reposition loss, but an inexpensive small-fragment screw or a wire will suffice. There is no consensus on the advisability of carrying out additional lateral release in the case of an incongruent metatarsophalangeal joint. We do not do so in the context of chevron osteotomy, for two reasons: (1) lateral release is unnecessary in mild deformities, and other procedures are available for more severe cases of hallux valgus; (2) lateral release increases the risk of poor perfusion of the head of metatarsal I with consequent necrosis. Postoperatively the toe must be held straight for 6 weeks with a corrective bandage. During this time the patient has to wear a flat-soled healing shoe that allows full weight bearing.

\section{Severe deformities}

Severe deformities mostly affect the middle-aged and elderly, predominantly women (Figure 5a) (1). The great toe can no longer be fully repositioned manually, and on radiographs the joint is seen to be incongruent, i.e. the proximal phalanx is subluxated laterally on the head of metatarsal I. The metatarsus is distinctly splayed, further increasing the prominence of the bunion on the medial aspect of the head of metatarsal I. The intermetatarsal angle is $15^{\circ}$ or more on weight bearing radiographs (3). In this case the soft tissues lateral to the first metatarsophalangeal joint must be divided - this is termed lateral release. Various versions of this soft tissue intervention have been known for many years and were particularly recommended by McBride (21). The technique most widely used today was first described by Mann (11). An intermetatarsal angle of $15^{\circ}$ or more necessitates an additional corrective osteotomy at the base of metatarsal I, where the potential for correction is greater (Figure 5b). Many different osteotomy techniques have been described. The simplest are opening osteotomies that are then filled medially with bone, for example from the resected exostosis. At the same time, osteotomies in two planes provide greater stability, because the bony contact surface is increased and the danger of dislocation reduced. After correction the osteotomy has to be stabilized with an implant. Here too, an inexpensive cancellous screw suffices. We take the view that complicated, costly implants such as fixed angle plates are unnecessary. When closing the capsule on the medial side of the metatarsophalangeal joint, the surgeon must take great care to ensure that the capsule is sufficiently tightened after resection of the bony pseudoexostosis.

\section{Hallux valgus et rigidus}

Osteoarthritis of the metatarsophalangeal joint is usually found in older patients. On closer inspection, most patients aged 65 years or more with hallux valgus show articular degeneration (Figure 6a). There is no longer any point in carrying out reconstructive procedures, because joint mobility is usually not adequately restored and long-term pain often results. The preferred procedure in physically inactive patients is therefore a very old intervention, namely resection arthroplasty with removal of the base of the proximal phalanx of the great toe $(16,17)$. The procedure is simple and the rehabilitation time short. In our experience the patients are moving around normally without special shoes within 4-6 weeks. One disadvantage is almost total loss of function of the great toe, which no longer has sufficient contact with the ground during the heel rise phase of gait. This frequently results in pain under the heads of the middle metatarsals, referred to as transfer metatarsalgia. Even pronounced deformities can be corrected, but generally

\section{Mild deformities}

Best suited for mild deformities are distal osteotomies of metatarsal I, particularly chevron osteotomy.

\section{Severe deformities}

Severe deformities necessitate soft tissue intervention around the first metatarsophalangeal joint, as a rule accompanied by an osteotomy at the base of metatarsal I. 
an accompanying osteotomy at the base of metatarsal I is required (Figure 7).

An alternative in patients with hallux valgus et rigidus who still have a high level of physical activity is arthrodesis of the joint. Contrary to the common expectation, arthrodesis is an operation that preserves function, because the great toe comes into firm contact with the ground during heel rise, relieving the metatarsal heads of the other rays. This means that a certain level of sporting activity is possible. A further advantage is the definitive positioning of the great toe. Thus arthrodesis can be considered especially for very pronounced deformities. In the presence of a greatly increased intermetatarsal angle, care must be taken to compress the metatarsus to enable proper adjustment of the angle between the proximal phalanx and metatarsal I. Fixation is achieved preferably with a dorsal plate (Figure 6b). This departs from strict biomechanical principles, but is practicable and successful. A tension screw may be added.

\section{Special cases}

Occasionally there are special indications. If the distal phalanx of the great toe is angled to lateral (hallux valgus interphalangeus), osteotomy of the proximal phalanx with removal of a medial-based wedge is required (generally in addition to one of the procedures described above) (8). Absolutely accurate restoration of the angle is not possible, but if the wedge has a base of 1 to $3 \mathrm{~mm}$ the correction is usually adequate. Complicated and costly implants (staples, screws) are available, but adequate fixation can be achieved with a simple, inexpensive suture threaded through drill holes. Occasionally the joint surface at the head of metatarsal I is tilted to lateral, particularly in cases where the hallux valgus arose before the patient reached adulthood. The orientation of the joint surface must then be corrected by osteotomy involving removal of a medialbased wedge from the distal portion of metatarsal I.

\section{Rehabilitation}

In our institution all operations on the forefoot are followed by full weight bearing in a postoperative shoe with a flat, stiff sole that is worn for 6 weeks. Because of the frequent tendency towards swelling, patients are advised to keep the affected foot raised for much of the time during the first 2 weeks. After reconstructive interventions a corrective dressing must be worn for up to 6 weeks. The patient changes the dressing each day.
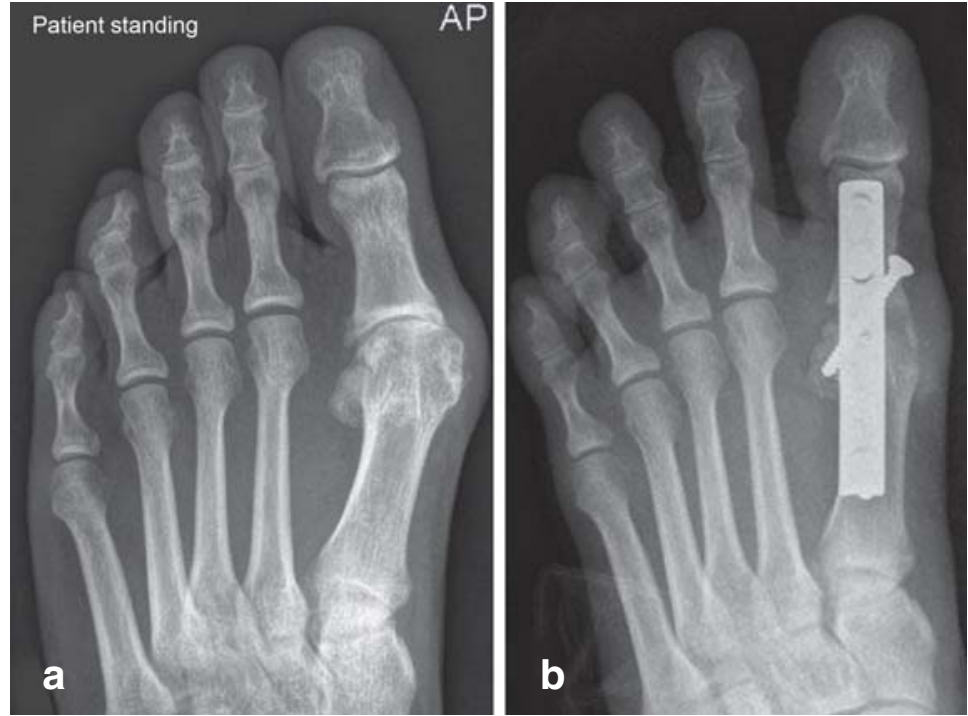

Figure 6: Radiographs of a foot with hallux valgus in a 68-year-old man a) Osteoarthritis of the first metatarsophalangeal joint with narrowing of the joint space

b) After arthrodesis. The patient wears a postoperative shoe with a stiff sole for 6 weeks and unlimited weight bearing is allowed immediately after surgery

Patients can usually walk normally after 8 to 12 weeks. Implants can be removed from 6 to 9 months after surgery, but can be left in situ in elderly patients if they are causing no symptoms.

\section{Conclusion}

The literature contains practically no well-controlled prospective trials; in particular, no comparison of different treatment procedures. Analysis of the large number of retrospective studies with follow-up for up to 5 years shows that overall, $85 \%$ of patients are satisfied and have a good clinical result. Ten percent are less satisfied and show a less beneficial outcome, and in 5\% the results of surgery are poor. This corresponds with our own experience. Foremost among the complications of reconstructive procedures are recurrences, sometimes as a result of inadequate surgical correction, sometimes because of poor wound healing (40). The quality of wound healing cannot be precisely predicted, and the rate of wound healing problems is generally stated as $2 \%$ to $4 \%$; our experience, however, indicates that this figure should be lower. Pseudarthrosis and necrosis of the head of metatarsal I are rare (e11, e12).

\section{Osteoarthritis}

In the presence of osteoarthritis of the first metatarsophalangeal joint and in very elderly patients, resection arthroplasty or arthrodesis of the first metatarsophalangeal joint produce the best results.

\section{Hallux valgus et rigidus}

There is no longer any point in carrying out reconstructive procedures, because joint mobility is usually not adequately restored and long-term pain often results. 

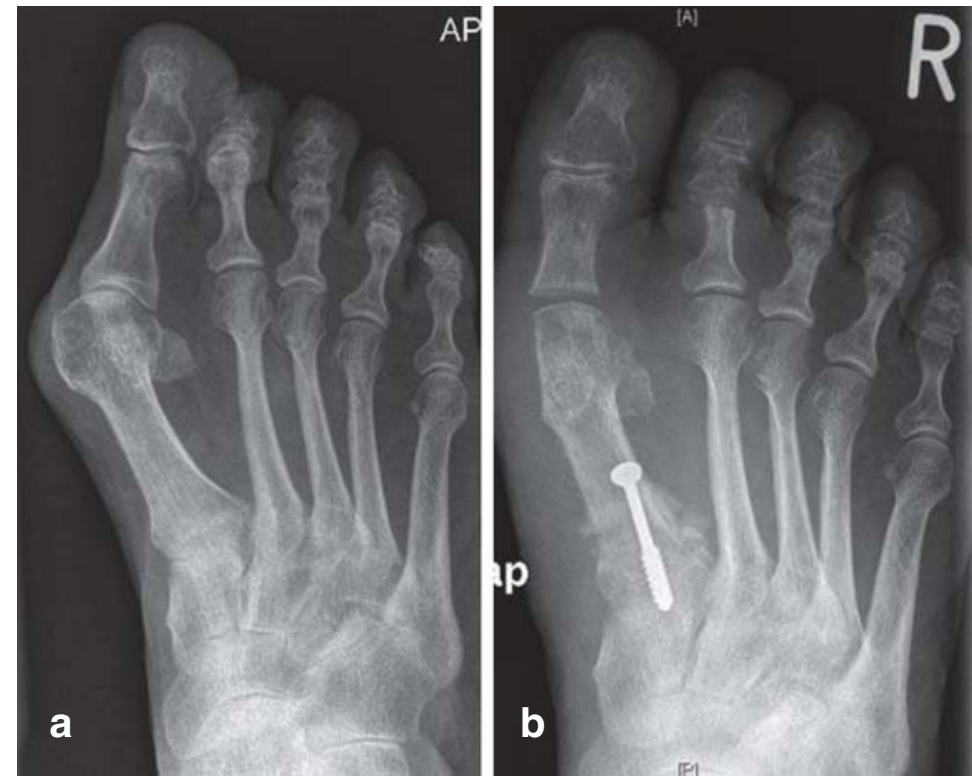

Figure 7: Radiographs of the right foot of a 75-year-old woman

a) Hallux valgus with slight narrowing of the joint space. The intermetatarsal angle is $17^{\circ}$

b) Because joint surface degeneration is regularly found at operation in patients of this age, the deformity was corrected by resection arthroplasty with a proximal osteotomy to correct the intermetatarsal angle

\section{Conflict of interest statement \\ The authors declare that no conflict of interest exists.}

Manuscript received on 30 March 2012, revised version accepted on 9 0ctober 2012

Translated from the original German by David Roseveare.

\section{REFERENCES}

1. Nix S, Smith M, Vicenzino B: Prevalence of hallux valgus in the general population: a systematic review and metaanalysis. J Foot Ankle Res 2010; 3: 21.

2. Nguyen US, Hillstrom HJ, Li W, et al.: Factors associated with hallux valgus in a population-based study of older women and men: the MOBILIZE Boston Study. Osteoarthritis Cartilage 2010; 18: 41-6.

3. Wülker N: Hallux valgus - Hallux rigidus. Stuttgart: Enke 1997; 3-32.

4. Mann RA, Coughlin MJ: Hallux valgus: etiology, anatomy, treatment and surgical considerations. Clin Orthop 1981; 157: 31-41.

5. Perera AM, Mason L, Stephens MM: The pathogenesis of hallux valgus. J Bone Joint Surg Am 2011; 93: 1650-61.

6. Wülker N: Hallux valgus. Orthopäde 1997; 26: 654-64.

7. Stinus H, Weber F: Einlagen bei Vorfußdeformitäten. Orthopäde 2005; 34: 776-81.
8. Akin OF: The treatment of hallux valgus: a new operative procedure and its results. Med Sentinel 1925; 33: 678-9.

9. Chacon Y, Fallat LM, Dau N, Bir C: Biomechanical Comparison of Internal Fixation Techniques for the Akin Osteotomy of the Proximal Phalanx. J Foot Ankle Surg 2012; 51: 561-5.

10. Kumar S, Pradhan R, Rosenfeld PF: First metatarsophalangeal arthrodesis using a dorsal plate and a compression screw. Foot Ankle Int 2010; 31: 797-801.

11. Mann RA, Rudicel S, Graves SC: Repair of hallux valgus with a distal soft-tissue procedure and proximal metatarsal osteotomy. A longterm follow-up. J Bone Joint Surg Am 1992; 74: 124-9.

12. Wülker N, Suckel A: Osteotomien des Mittelfußes beim Hallux valgus. Orthopäde 2005; 34: 726-34.

13. Austin DW, Leventeen EO: A new osteotomy for hallux valgus. Clin Orthop 1981; 157: 25-30.

14. Hohmann G: Über Hallux valgus und Spreizfuß, ihre Entstehung und physiologische Behandlung. Arch Orthop Unfall Chir 1923; 21: $525-50$.

15. Hueter K: Klinik der Gelenkkrankheiten. Leipzig 1871.

16. Keller WL: The surgical treatment of bunions and hallux valgus. NY Med J 1904; 80: 741-2.

17. Brandes M: Zur operativen Therapie des Hallux valgus. Zbl Chir 1929; 56: 2434-40

18. Kramer J: Die Kramer-Osteotomie zur Behandlung des Hallux valgus und des Digitus quintus varus. Operat Orthop Traumatol 1990; 2: 14-38.

19. Lapidus PW: Operative correction of metatarsus varus primus in hallux valgus. Surg Gynecol Obstet 1934; 58: 183-91.

20. Taylor NG, Metcalfe SA: A review of surgical outcomes of the Lapidus procedure for treatment of hallux abductovalgus and degenerative joint disease of the first MCJ. Foot (Edinb) 2008; 18: 206-10.

21. Mc Bride ED: A conservative operation for bunions. J Bone Joint Surg 1928; 10: 735-9.

22. Weil LS: Scarf osteotomy for correction of hallux valgus. Historical perspective, surgical technique, and results. Foot Ankle Clin 2000; 5: 559-80.

23. Klosok JK, Pring DJ, Jessop JH, Maffulli N: Chevron or Wilson metatarsal osteotomy for hallux valgus. A prospective randomised trial. J Bone Joint Surg Br 1993; 75: 825-9.

24. Resch S, Stenström A, Reynisson K, Jonsson K: Chevron osteotomy for hallux valgus not improved by additional adductor tenotomy. A prospective, randomized study of 84 patients. Acta Orthop Scand 1994; 65: 541-4.

25. Connor JC, Berk DM, Hotz MW: Effects of continuous passive motion following Austin bunionectomy. A prospective review. J Am Podiatr Med Assoc 1995; 85: 744-8.

26. Easley ME, Kiebzak GM, Davis WH, Anderson RB: Prospective, randomized comparison of proximal crescentic and proximal chevron osteotomies for correction of hallux valgus deformity. Foot Ankle Int 1996: 17: 307-16.

27. Calder JD, Hollingdale JP, Pearse MF: Screw versus suture fixation of Mitchell's osteotomy. A prospective, randomised study. J Bone Joint Surg Br 1999; 81: 621-4.

\section{Rehabilitation}

As a rule rehabilitation is very functional, usually with full load bearing in a flat healing shoe.

\section{Wound healing problems}

The frequency of wound healing problems is generally stated as $2 \%$ to $4 \%$. 
28. Torkki M, Malmivaara A, Seitsalo S, Hoikka V, Laippala P, Paavolainen P: Hallux valgus: immediate operation versus 1 year of waiting with or without orthoses: a randomized controlled trial of 209 patients. Acta Orthop Scand 2003; 74: 209-15.

29. Faber FW, Mulder PG, Verhaar JA: Role of first ray hypermobility in the outcome of the Hohmann and the Lapidus procedure. A prospective, randomized trial involving one hundred and one feet. J Bone Joint Surg Am 2004; 86-A(3): 486-95.

30. Saro C, Andrén B, Wildemyr Z, Felländer-Tsai L: Outcome after distal metatarsal osteotomy for hallux valgus: a prospective randomized controlled trial of two methods. Foot Ankle Int 2007; 28: 778-87.

31. Deenik A, van Mameren $H$, de Visser $E$, de Waal Malefijt M, Draijer $\mathrm{F}$, de Bie R: Equivalent correction in scarf and chevron osteotomy in moderate and severe hallux valgus: a randomized controlled trial. Foot Ankle Int 2008; 29: 1209-15.

32. Tonbul M, Baca E, Ada M, Ozbaydar MU, Yurdoðlu HC: Crescentic distal metatarsal osteotomy for the treatment of hallux valgus: a prospective, randomized, controlled study of two different fixation methods. Acta Orthop Traumatol Turc 2009; 43: 497-503.

33. du Plessis M, Zipfel B, Brantingham JW, et al.: Manual and manipulative therapy compared to night splint for symptomatic hallux abducto valgus: an exploratory randomised clinical trial. Foot (Edinb) 2011; 21: 71-8.

34. Pentikäinen IT, Ojala R, Ohtonen P, Piippo J, Leppilahti J: Radiographic analysis of the impact of internal fixation and dressing choice of distal chevron osteotomy: randomized control trial. Foot Ankle Int 2012; 33: 420-3.
35. Ferrari J, Higgins JP, Prior TD: Interventions for treating hallux valgus (abductovalgus) and bunions. Cochrane Database Syst Rev 2004; (1): CD000964. Review. Update in: Cochrane Database Syst Rev 2009; (2): CD000964.

36. Richter M: Aktualisierte Leitlinien Fuß und Sprunggelenk. Fuss Sprung 2010; 8: 268-87.

37. Wanivenhaus A, Bock P, Gruber F, et al.: Deformitätsassoziierte Behandlung des Hallux-valgus-Komplexes. Orthopade 2009; 38:1117-26.

38. Wülker N: Allgemeine Operationstechnik an Fuß und Sprunggelenk. Orthopäde. 2011; 40: 378-83.

39. Wülker N, Stephens MM, Cracchiolo A III: Operationsatlas Fuß und Sprunggelenk. Stuttgart: Thieme 2007; 3-64.

40. Wülker N: Fehlschläge in der Hallux-valgus-Chirurgie. Orthopäde 2011; 40: 384-91.

\section{Corresponding autho}

Prof. Dr. med. Nikolaus Wülker

Orthopädische Universitätsklinik

Hoppe-Seyler-Str. 3

72076 Tübingen, Germany

wuelker@med.uni-tuebingen.de

Vor eReferences please refer to:

www.aerzteblatt-international.de/ref4912

Further Information on CME

This article has been certified by the North Rhine Academy for Postgraduate and Continuing Medical Education.

Deutsches Ärzteblatt provides certified continuing medical education (CME) in accordance with the requirements of the Medical Associations of the German federal states (Länder). CME points of the Medical Associations can be acquired only through the Internet, not by mail or fax, by the use of the German version of the CME questionnaire within 6 weeks of publication of the article. See the following website: cme.aerzteblatt.de

Participants in the CME program can manage their CME points with their 15-digit "uniform CME number" (einheitliche Fortbildungsnummer, EFN) The EFN must be entered in the appropriate field in the cme.aerzteblatt.de website under "meine Daten" ("my data"), or upon registration. The EFN appears on each participant's CME certificate.

The solutions to the following questions will be published in issue 5/2013. The CME unit "The Diagnosis and Management of Dyscalculia" (issue 45/2012) can be accessed until 21 December 2012.

For issue 1-2/2012, we plan to offer the topic "Competitive sports and the heart: benefit or risk?."

Solutions to the CME questionnaire in issue 41/2012:

Schmidt-Chanasit J, et al.: Viruses acquired abroad—what does the primary care physician need to know?

Solutions: 1e, 2c, 3c, 4d, 5e, 6a, 7c, 8c, 9e, 10d 


\section{Please answer the following questions to participate in our certified Continuing Medical Education program. Only one answer is possible per question. Please select the answer that is most appropriate.}

\section{Question 1}

The hallux valgus deformity consists principally of lateral deviation of the great toe. However, there are further deviations from normal forefoot anatomy. Which of the following is one of these?

a) A prominence on the medial aspect of the head of metatarsal $V$

b) Shortening of the Achilles tendon

c) Pronation of the whole foot

d) Widening of the metatarsus (splay foot)

e) Excessive shortness of metatarsal IV

\section{Question 2} diagnostic examination is required. What is it?
a) Weight bearing radiograph in dorsoplantar projection
b) Magnetic resonance imaging of the forefoot
c) Bone scintigraphy
d) Lateral radiography of the forefoot without load
e) Sonography of the metatarsophalangeal joint

\section{Question 3}

How can lasting correction of hallux valgus deformity in an adult be achieved by conservative means?
a) Insoles with a pad
b) Soft shoes
c) Night splints
d) Cannot be achieved
e) Splay foot bandage

\section{Question 4}

When is surgical correction of hallux valgus indicated?

a) When high-heeled shoes can no longer be worn

b) When the symptoms regularly cause noticeable limitation of daily activities

c) When the radiograph shows a hallux valgus angle of more than $20^{\circ}$

d) When night splints do not improve the position of the great toe

e) When degenerative changes in the first metatarsophalangeal joint can be seen on magnetic resonance imaging
When surgical correction of hallux valgus is indicated, a further

Question 6

What is one of the characteristics of mild hallux valgus deformity?

a) Limited mobility of the first metatarsophalangeal joint

b) Simultaneous claw toe

c) A flexible deformity

d) An intermetatarsal angle of more than $15^{\circ}$

e) Osteoarthritis of the first metatarsophalangeal joint on radiography

\section{Question 7}

What is one of the findings in severe hallux valgus deformity?
a) An incongruence (subluxation) of the first metatarsopha- langeal joint on radiography
b) An intermetatarsal angle of less than $10^{\circ}$
c) Osteoporosis
d) Absent pedal pulse
e) Simultaneous flat foot

\section{Question 8}

Which operation for hallux valgus is particularly suitable for older, inactive patients who also have painful osteoarthritis of the first metatarsophalangeal joint?

a) Chevron osteotomy

b) Distal soft tissue intervention with basal osteotomy

c) Distal osteotomy of metatarsal I

d) Corrective osteotomy of the proximal phalanx

e) Resection arthroplasty

\section{Question 9}

What should always be observed in operations for hallux valgus?

a) Extensive hemostasis by means of electrocautery

b) Loose wound bandage without compression

c) As little dissection of soft tissues as possible

d) Ischemia for as long as possible

e) Suture removal after about a week

\section{Question 10}

What is an advantage of Chevron osteotomy?

correction of hallux valgus?
a) A peripheral perfusion disorder
b) Chronic polyarthritis
c) Diabetes mellitus
d) Bilateral hallux valgus
e) Osteoarthritis of the first metatarsophalangeal joint
a) Complete soft tissue correction
b) Can be used in severe deformities
c) No implant necessary
d) Little soft tissue trauma
e) Good perfusion of the head of metatarsal I 


\section{CONTINUING MEDICAL EDUCATION}

\section{The Treatment of Hallux Valgus}

Nikolaus Wülker, Falk Mittag

eReferences

e1. Coughlin MJ: Etiology and treatment of the bunioette deformity. Instr Course Lect 1990; 39: 37-48.

e2. Coughlin MJ: Roger A. Mann Award. Juveline hallux valgus: etiology and treatment. Foot Ankle Int 1995; 16: 682-97.

e3. Coughlin MJ, Mann RA: The pathophysiology of the juveline bunion. Instr Course Lect 1987; 36: 123-36.

e4. Arnold H: The Akin procedure as closing wedge osteotomy for the correction of a hallux valgus interphalangeus deformity. Oper Orthop Traumatol 2008; 20: 477-83.

e5. Schnirring-Judge M: Technique and pearls in performing the first metatarsal phalangeal joint arthrodesis. Clin Podiatr Med Surg 2011; 28: 345-59.

e6. Mayo CH: The surgical treatment of bunions. Minn Med J 1908; 326-31.

e7. Hyer CF, Saxena A, Didomenico L: Lapidus arthrodesis. J Foot Ankle Surg 2011; 50: 784-5.

e8. Patton GW; Zelichowski JE: Middiaphyseal osteotomies. In: Hetherington VJ (ed.): Hallux valgus and forefoot surgery. New York: Churchill Livingstone 1994; 215-25.

e9. Adam SP, Choung SC, Gu Y, O'Malley MJ: Outcomes after scarf osteotomy for treatment of adult hallux valgus deformity. Clin Orthop Relat Res 2011; 469: 854-9.

e10. Williams DT, Price P, Harding KG: The influence of diabetes and lower limb arterial disease on cutaneous footperfusion. J Vasc Surg 2006; 44: 770-5.

e11. Lehman DE: Salvage of complications of hallux valgus surgery. Foot Ankle Clin 2003; 8: 15-35.

e12. Sammarco GJ, Idusuyi OB: Complications after surgery of the hallux. Clin Orthop Relat Res 2001; 391: 59-71. 